\title{
Investigation of childhood traumas in inpatient adults with major depression and with or without attention deficit hyperactivity disorder comorbidity
}

\author{
Yatarak tedavi gören major depresyon ve dikkat eksikliği hiperaktivite \\ bozukluğu eş tanısı olan ve olmayan erişkinlerde çocukluk çă̆ı \\ travmalarının incelenmesi
} Esin Erdoğan1, Dursun Hakan Delibaş1, Emel Pasa Baskin²
${ }^{1}$ M.D., 2PhD., University of Health Sciences, Izmir Bozyaka Training and Research Hospital, Department of Psychiatry, Izmir, Türkiye
https://orcid.org/0000-0003-0100-652X-https://orcid.org/0000-0001-5907-415X-https://orcid.org/0000-0002-5423-6102

\section{SUMMARY}

Objective: Attention deficit hyperactivity disorder (ADHD) is one of the most common neurodevelopmental disorders of childhood and a significant number of symptoms continue in adulthood. Depression is very common in the daily practice of psychiatrists whereas patients with ADHD comorbidity could not be considered by the clinicians. One of the less studied aspects of adult ADHD is its association with childhood traumas. The aim of this study was to compare adults with major depression (MD) with or without ADHD comorbidity (MD-ADHD) in terms of childhood traumas and the severity of psychopathology. Method: 33 inpatients with MD-ADHD and 30 inpatients with MD were included in the study. The diagnoses were made according to DSM-V criteria, and sociodemographic evaluation scale, Wender Utah Rating Scale (WURS), Adult Attention Deficit Hyperactivity Disorder Scale (A-ADHDS), Hamilton Depression Scale (HDS), Childhood Trauma Questionnaire (CTQ), and Personal Social Performance Scale (PSPS) were applied to the patients. Results: The mean HDS scores of MD-ADHD patients during hospitalization were higher $(p=0.007)$, total CTQ scores were higher $(p=0.006)$, and mean PSPS scores were lower than the MD group $(p=0.012)$. The mean scores of emotional abuse, physical neglect, and physical abuse were higher in MD-ADHD patients $(p=0.013 ; p=0.017$; $p=0.016$; respectively). All trauma scores except emotional neglect and sexual abuse were higher in combined type ADHD than the other two groups. Discussion: Depression patients with comorbid ADHD had more severe depression level and lower functionality compared to those with depression alone. It is important to investigate the history of childhood traumas in adults with depression and ADHD comorbidity.

Key Words: depression, adult attention deficit hyperactivity disorder, childhood trauma

(Turkish J Clinical Psychiatry 2020;23:56-63)

DOI: $10.5505 / \mathrm{kpd} .2020 .54765$

\section{ÖZET}

Amaç: Dikkat eksikliği hiperaktivite bozukluğu (DEHB) çocukluk döneminin sık rastlanan nörogelişimsel bozuklarından olup belirtilerin önemli bir bölümü erişkin dönemde de devam etmektedir. Depresyon psikiyatristlerin günlük pratiğinde çok sık yer alırken DEHB'nin birlikte görüldüğü olgular klinisyenlerin dikkatinden kaçabilmektedir. Erişkin DEHB'nin daha az araştırılan bir yönü de çocukluk çağı örselenmeleriyle olan ilişkisidir. Bu çalışmada DEHB eş tanısı olan (MD-DEHB) ve olmayan major depresyon (MD) tanılı erişkinlerin çocukluk çağı örselenmeleri ve psikopatoloji şiddeti açısından karşılaştırılması amaçlanmıştır. Yöntem: Araştırmaya yatarak tedavi gören 33 MD-DEHB, 30 MD tanılı olgu alındı. Tanılar DSM-V ölçütlerine göre konulmuş, olgulara sosyodemografik değerlendirme ölçeği, Wender Utah Derecelendirme Ölçeği (WUDÖ), Erişkin Dikkat Eksikliği Hiperaktivite Bozukluğu Ölçeği (E-DEHBÖ), Hamilton Depresyon Ölçeği (HDÖ), Çocukluk Çağı Travmaları Ölçeği (ÇÇTÖ), Bireysel Sosyal Performans Ölçeği (BSPÖ) uygulanmıştır. Bulgular: MD-DEHB'lilerin diğer gruba göre yatış sırasındaki ortalama HDÖ puanı $(p=0.007)$, toplam ÇÇTÖ puanları daha yüksek $(p=0.006)$, BSPÖ puanları ise daha düşüktü $(p=0.012)$. Duygusal istismar, fiziksel ihmal, fiziksel istismar ortalama puanları MDDEHB'lilerde daha yüksekti $(p=0.013 ; p=0.017$; $p=0.016$ ). Bileşik tip DEHB'de duygusal inmal ve cinsel istismar dışındaki tüm travma puanları diğer iki gruptan daha yüksekti. Sonuç: DEHB eş tanısı olan depresyon hastaları sadece depresyonu olanlara göre daha şiddetli depresyon düzeyi ve daha düşük işlevsellik gösterdi. Depresyon ve DEHB birlikteliğinde, erişkinlerde çocukluk çağı travma öyküsünün sorgulanması önemlidir.

Anahtar Sözcükler: Depresyon, erişkin dikkat eksikliği hiperaktivite bozukluğu, çocukluk çağı travması 


\section{INTRODUCTION}

Attention deficit hyperactivity disorder (ADHD) has been described as a neurodevelopmental disorder that continues with chronic attention deficit and/or hyperactivity-impulsivity symptoms in adults (1). The classic symptoms of ADHD in adulthood cover a broad spectrum that ranges from normal to a high level of impulsivity and irritability that would require initiating medical treatment. However, the diagnosis of ADHD by clinicians is not easy due to high rates of comorbidity with mood and anxiety disorders (2).

There are many definitions of neglect and abuse in the literature. This definition varies depending on various factors such as the nature of the study, the sociocultural environment, and the intent behind the behavior. The most universal definition of child neglect and abuse is any action or inaction that involves physical, emotional, sexual abuse preventing or slowing down the optimal development of the child. The effects of trauma on child development and behavior are complex and multifaceted. According to the theory of development (3), maltreatment of children adversely affects sensory, cognitive, and mood-related areas. Many studies have been reported important relationships between ADHD and childhood traumas $(4,5)$. Children diagnosed with ADHD are more likely to be exposed to violent behavior due to the biological nature of ADHD as well as the mutual interaction of environmental factors, and they are at a higher risk of child abuse compared to their peers who are not diagnosed with ADHD (6). It is known that the effects of abuse and ADHD persist in adulthood and these effects are associated with adverse life events, various psychopathologies, and loss of psychosocial functioning (occupational, marriage, parenting roles). When the literature is examined, it is seen that all these risks increase when ADHD and abuse are concomitant (7). It has been emphasized that public health policies are particularly important for early recognition and prevention of physical abuse, one of childhood traumas with long-lasting harmful effects (5).

The relationship between ADHD and childhood traumas in the adults has not been studied as inten- sively as in children. Matsumoto and Imamura investigated the relationship between childhood trauma history, childhood ADHD symptoms and dissociation in adulthood in a prison sample and reported that the frequency of these problems was higher than the general population (8). Semiz et al. (2012) compared adults with ADHD diagnosis according to DSM-IV criteria with healthy controls in terms of physical-emotional abuse, neglect and negative childhood experiences. They reported that negative childhood experiences and emotional abuse and neglect were more common in ADHD cases compared to the control group (9).

Major depressive disorder is among the most common comorbidities with ADHD. It has been reported that there are many problems in education, work, peer relations, social, occupational, and legal fields in cases where depression is comorbid with ADHD (10). When the studies analyzing the relationship between depression and trauma were examined, rate of emotional abuse was higher in adults with a diagnosis of mood and anxiety disorder (11). In another study comparing recurrent major depression group and first episode major depression group, childhood trauma scores were higher in the recurrent major depression group, and a strong relationship was found between childhood trauma and early onset of depression (12). In studies examining the relationship between depression and anxiety, it was found that childhood traumas increased the comorbidity of these disorders (13) and decreased the response to treatment (14). Researchers emphasized that multiple childhood traumas play an important role in depression to become a chronic disorder (15). These findings particularly support the role of emotional neglect and emotional abuse in relation to depression. It has been noted that sexual/physical abuse or violence in the family may be non-specific risk factors for mental disorders (15). Although studies to date have reported that childhood trauma is common in both ADHD and depression, it is noteworthy that cases with depression and ADHD comorbidity are not examined in the samples of these studies. This raises the question: "Does this risk increase in the concomitance of depression and ADHD?"

The aim of this study was to compare adult major depression patients with and without ADHD 
comorbidity in terms of childhood traumas. Our hypothesis is that there will be a higher rate of childhood trauma in depression patients with ADHD comorbidity compared to the non-ADHD group, and that psychopathology will be more severe in depression patients with ADHD.

\section{METHOD}

In this study, 71 patients between 18-65 age who were consecutively hospitalized in the psychiatry clinic between June 2014 and June 2015 with the diagnosis of major depression were evaluated to be included in the study and 63 patients were included in the study. 8 patients were excluded from the study due to various reasons $(n=3$ not wanting to participate in the study, $n=3$ early discharge, $n=2$ additional medical comorbidities). Illiterate patients, patients with mental retardation, patients with schizophrenia, patients with bipolar disorder, substance use in the last 3 months, neurological and medical diseases affecting the central nervous system, were not included in the study. The study was approved by the local ethics committee of the hospital in accordance with the Helsinki Declaration. After the study protocol was explained, written informed consent was obtained from all participants. Cases were evaluated by sociodemographic evaluation scale, Wender-Utah Rating Scale Turkish Form (WURS), Adult Attention Deficit Hyperactivity Disorder Scale (AADHDS), Hamilton Depression Scale (HDS), Childhood Trauma Questionnaire-short form (CTQ), and Personal and Social Performance Scale.

The diagnosis of ADHD and depression was made through criteria based on DSM-V by two psychiatrists (EE, DHD). Patients with a psychiatric diagnosis other than ADHD and depression were excluded. Cases with a Hamilton Depression Scale (HDS) above 16 points during hospitalization were included in the study. WURS was applied to predict and support ADHD diagnosis in childhood in cases with ADHD comorbidity. The WURS results were above 36 points in all patients diagnosed with ADHD by clinical examination.

\section{Data Collection Tools}

Sociodemographic evaluation scale: It was prepared by the researchers. Age, gender, educational status, marital status, economic status, and some clinical characteristics such as length of hospital stay, previous suicide attempt were questioned with this form and recorded.

Wender-Utah Rating Scale Turkish Form (WURS): It is a likert-type self-report scale rated between 0-4, analyzing childhood ADHD symptoms. It is used to support the diagnosis of ADHD in adults (18). The validity and reliability study of the Turkish version has been performed (19). As suggested by Öncü et al., scores above 36 points were accepted as cut-off point for ADHD in this study.

Adult Attention Deficit Hyperactivity Disorder Scale $(A-A D H D S)$ : It is a 4-point likert-type rating scale designed to examine the symptoms of attention deficit, hyperactivity and impulsivity in adults (20). It consists of three sub-dimensions: Attention Deficit Dimension (ADD), Hyperactivity/ Impulsivity Dimension, and characteristics related to ADD/ADHD. The Turkish validity and reliability study has been performed (21).

Hamilton Depression Scale (HDS): Developed by Hamilton (22), it is a scale used to measure the severity of depression and the changes in severity of depression in follow-up. The Turkish validity and reliability study was performed by Akdemir et al. (23).

Childhood Trauma Questionaire-Short Form (CTQ): This scale was developed as 70 items by Bernstein in 1994 (24), and then reduced to 54 items in 1995 and adapted to Turkish in 1996 by Şar (25). It is a 5-point likert-type self-report scale. It includes questions about emotional, physical, sexual abuse and physical and emotional neglect in childhood. Şar et al. (2012) conducted the reliability and validity study of the scale and found that the scale had 5 factors. These were physical abuse, sexual abuse, emotional abuse, physical neglect, and emotional neglect. The findings of this study suggest that obtaining more than 5 points for sexual and physical abuse, in other words, a "Yes" answer to any of 
the questions albeit at the lowest level should be considered as positive statement. For physical neglect and emotional abuse, this cut-off value is 7 points, and for emotional neglect it is 12 points. It could be noted that the cut-off value for the total scale is around 35. Furthermore, the high correlations obtained between the 28 -item current version of the scale and the 54-item previous version show that the findings obtained in the studies conducted with both versions of the scale are comparable.

Personal and Social Performance Scale (PSPS): It is a 6-point likert-type scale that evaluates functionality in four dimensions (26). In the PSPS scale, higher scores indicate higher functionality. Validity and reliability study of the Turkish version was performed by Aydemir et al. (27).

\section{Data Analysis}

All data were analyzed with SPSS 21 statistical package program. Mean, standard deviation and percentage distributions were used as part of descriptive statistical methods. Student $t$ test was used as part of parametric tests to compare the data, and Chi-square test was used to compare categorical variables. One-way analysis of variance (ANOVA) for independent samples was used to examine the difference between more than two groups. $\mathrm{P}<0.05$ was considered statistically significant.

\section{RESULTS}

$52.4 \%(n=33)$ of the cases were female and $47.6 \%$ $(n=30)$ were male. The mean age was $40.27 \pm 9.6$ years. There was no statistically significant difference between the MD-ADHD comorbidity group and the MD group in terms of age $(p=0.703)$, gender $(p=0.928)$, and education $(p=0.93)$ (Table 1$)$.

At the time of hospitalization, MD-ADHD patients

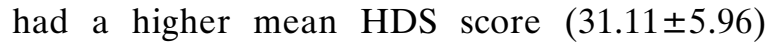
$(p=0.007)$ and a lower mean PSPS score in terms of functionality $(37.86 \pm 11.62)(p=0.012)$ compared to the MD patients (Table 1). There was no statistically significant difference between two groups in terms of length of hospitalization $(p=0.189)$. When the two groups were compared in terms of lifetime suicide attempt, the rate of lifetime suicide attempt was higher in the MD-ADHD group and a statistically significant difference was found between the groups $(\mathrm{df}=1, \mathrm{p}=0.039)$. In depression patients with ADHD comorbidity, the mean total CTQ score was significantly higher $(\mathrm{p}=0.006)$.

No statistically significant difference was found in terms of emotional neglect and sexual abuse scores in depression patients with and without ADHD comorbidity. When the mean scores of emotional abuse $(p=0.013)$, physical abuse $(p=0.016)$, and physical neglect $(p=0.017)$ were evaluated, there

Table 1. Comparison of some sociodemographic and clinical characteristics of major depression patients with and without ADHD comorbidity

\begin{tabular}{|c|c|c|c|}
\hline Mean \pm SD or $\mathrm{n}(\%)$ & $\begin{array}{l}\text { MD } \\
(n=30)\end{array}$ & $\begin{array}{l}\text { MD+ADHD } \\
(n=33)\end{array}$ & $\mathbf{p}$ \\
\hline Age & $40.89 \pm 10.63$ & $39.70 \pm 11.20$ & $T=0.383 p=0.703$ \\
\hline \multicolumn{4}{|l|}{ Sex } \\
\hline Female $\quad(n=33)$ & $\% 47.4$ & $\% 48.6$ & $x^{2}=0.008 p=0.928$ \\
\hline Male $(n=30)$ & $\% 52.6$ & $\% 51.4$ & \\
\hline Education (year) & $9.16+4.47$ & $9.11+4.30$ & $z=-0.81 \quad p=0.93$ \\
\hline Hospitalisation length (day) & $28.98 \pm 18.46$ & $30.68 \pm 14.60$ & $z=-0.78 \quad p=0.189$ \\
\hline A-ADHDS-1 score & $3.32+3.08$ & $15.68+5.74$ & $z=-2.812 p=0.000$ \\
\hline A-ADHSS-2 score & $1.88 \pm 1.23$ & $13.47 \pm 6.32$ & $z=2.715 p=0.000$ \\
\hline A-ADHDS-3 score & $14.46 \pm 9.36$ & $48.56 \pm 24.04$ & $z=-2.648 p=0.000$ \\
\hline WURS & $19.86 \pm 13.47$ & $56.42 \pm 25.66$ & $z=-2.438 p=0.000$ \\
\hline HDS- admission & $25.52 \pm 7.54$ & $31.11 \pm 5.96$ & $z=-2.682 p=0.007$ \\
\hline HDS-discharge & $17.23 \pm 4.84$ & $22.02 \pm 5.70$ & $z=-2.745 p=0.004$ \\
\hline PSPS-admission & $45.17 \pm 10.98$ & $37.86+11.62$ & $z=-2.453 p=0.012$ \\
\hline PSPS-discharge & $64.05 \pm 22.45$ & $67.72 \pm 13.54$ & $z=-0.315 p=0.753$ \\
\hline CTQ-total score & $45.42+14.11$ & $59.11+20.60$ & $z=-2.649 p=0.006$ \\
\hline
\end{tabular}

SD: Standard Deviation, MD: Major Depression, ADHD: Attention Deficit Hyperactivity Disorder, A-ADHDS: Adult Attention Deficit Hyperactivity Disorder Scale, HDS: Hamilton Depression Scale, PSPS: Personal Social Performance Scale,

CTQ: Childhood Trauma Questionaire-Short Form, $\mathrm{p}<0.05$ was considered as statistically significant 
Erdogan E, Delibas DH, Pasa Baskin E.

Tablo 2. Comparison of the mean sub-scale scores of the major depression patients with and without ADHD comorbidity.

\begin{tabular}{llll}
\hline & $\begin{array}{l}\text { MD } \\
(\mathbf{n}=\mathbf{3 0}) \\
\text { Mean } \pm \text { SD }\end{array}$ & $\begin{array}{l}\text { MD+ADHD } \\
(\mathbf{n = 3 3}) \\
\text { Mean } \pm \text { SD }\end{array}$ & $\mathbf{p}$ \\
\hline CTQ-Emotional abuse & $8.79 \pm 3.56$ & $13.14 \pm 6.17$ & $\mathrm{z}=-2.47 \quad \mathbf{p = 0 . 0 1 3}$ \\
\hline CTQ-Physical abuse & $8.53 \pm 5.43$. & $11.46 \pm 5.83$ & $\mathrm{z}=-2.45 \quad \mathbf{p = 0 . 0 1 6}$ \\
\hline CTQ-Physical neglect & $8.95 \pm 3.90$ & $11.43 \pm 4.48$ & $\mathrm{z}=-2.381 \quad \mathbf{p}=\mathbf{0 . 0 1 7}$ \\
\hline CTQ-Emotional neglect & $13.16 \pm 3.89$ & $14.43 \pm 5.54$ & $\mathrm{z}=-.695 \quad \mathrm{p}=0.487$ \\
\hline CTQ-Sexual abuse & $7.68 \pm 3.85$ & $9.62 \pm 6.20$ & $\mathrm{z}=-0.925 \mathrm{p}=0.355$ \\
\hline
\end{tabular}

SD: Standard Deviation, MD: Major Depression, ADHD: Attention Deficit Hyperactivity Disorder,

CTQ: Childhood Trauma Questionaire-Short Form, $\mathrm{p}<0.05$ was considered as statistically significant

were statistically significant differences between the groups (Table 2).

Childhood trauma scores according to ADHD subtypes in depression patients with ADHD comorbidity were compared in Table 3 . The mean scores of all trauma subtypes were higher in combined type ADHD.

\section{DISCUSSION}

In this study, adult depression patients with ADHD comorbidity were compared with gender, age, and education-matched adult depression patients in terms of childhood traumas. It was found that childhood trauma rates were higher in the depression group with ADHD comorbidity.

In the literature, it has been suggested that depression treatment and prognosis is adversely affected in adults with ADHD $(28,29)$, suicidal behavior increases due to impulsivity, and ADHD increases suicide risk by worsening depression (30). In our study, depression scale scores were higher and individual and social performance scores were lower in adults with ADHD at the time of hospitalization. At the time of discharge, although depression scale scores of the patients with depression and ADHD comorbidity were higher, there was no difference between the two groups in terms of individual and social performances. We think that this may be due to the discharge decisions made based on the patient's functionality. Furthermore, consistent with the results of previous studies $(31,32)$, lifetime suicidal attempt rates were found to be higher in the ADHD group in this study. In the light of the literature data above and the findings of our study, it is important to evaluate ADHD comorbidity by clinicians in patients with treatment-resistant depression and individual and social dysfunction. More comorbidities and higher treatment costs were observed in adults with ADHD (33-35). Imagawa et al. reported that the mean length of hospitalization in cases with ADHD comorbidity was 22 days (35). In the present study, we could not find any difference between the groups in terms of length of hospitalization. However, this may be related to the characteristics of our clinic where mean hospitalization length does not exceed one month due to the intensity of the need for hospitalization.

Childhood trauma is seen in many psychiatric disorders (15). The presence of childhood trauma adversely affects the course of the accompanied psychiatric condition and its outcomes become more severe (36). In studies conducted on children with ADHD, it has been reported that childhood trauma history is common and traumatic experiences adversely affect prognosis $(37,38)$. There are studies in the literature suggesting that adult

Tablo 3. Comparison of childhood trauma scores according to ADHD subtypes in depression patients with ADHD comorbidity

\begin{tabular}{llllll}
\hline & $\begin{array}{l}\text { ADHD- } \\
\text { inattention } \\
\text { Mean } \pm \text { SD }\end{array}$ & $\begin{array}{l}\text { ADHD- } \\
\text { hyperactiv/impulsivity } \\
\text { Mean } \pm \text { SD }\end{array}$ & $\begin{array}{l}\text { ADHD-combined } \\
\text { Mean } \pm \text { SD }\end{array}$ & $\mathrm{p}$ & Post-hoc groups evaluation \\
\hline CTQ-emotional abuse & $9.73 \pm 5.53$ & $9.20 \pm 5.02$ & $15.86 \pm 5.48$ & 0.010 & Combined $>$ Inattention=Hyperactive/Impul. \\
\hline CTQ- physical abuse & $7.82 \pm 3.92$ & $9.60 \pm 4.77$ & $13.81 \pm 5.55$ & 0.021 & Combined $>$ Hyperactive/Impul.=Inattention \\
\hline CTQ-physical neglect & $8.64 \pm 2.76$ & $7.80 \pm 2.77$ & $13.76 \pm 4.18$ & 0.008 & Combined $>$ Inattention=Hyperactive/Impul \\
\hline CTQ-emotional neglect & $11.82 \pm 5.89$ & $11.00 \pm 5.24$ & $16.62 \pm 455$ & 0.349 & Combined $>$ Inattention=Hyperactive/Impul \\
\hline CTQ-sexual abuse & $8.36 \pm 3.80$ & $7.60 \pm 3.28$ & $10.76 \pm 7.52$ & 0.847 & Combined=Hyperactive/Impul.=Inattention \\
\hline CTQ-total score & $44.83 \pm 17.34$ & $50.62 \pm 24.2$ & $68.42 \pm 17.88$ & 0.002 & Combined $>$ Hyperactive/Impul.=Inattention \\
\hline SD: Standard Deviation, ADHD: Attention Deficit Hyperactivity Disorder, CTQ: Childhood Trauma QuestionaireShort Form, $<<0.05$ was considered as statistically significant
\end{tabular}


ADHD patients are more likely to experience childhood traumatic events $(39,40)$. In our study, a significant difference was found between the patients diagnosed with depression and the patients with depression and ADHD comorbidity in terms of childhood traumas. Depressive patients with ADHD reported more traumatic childhood experiences in all areas of trauma, except for emotional neglect and sexual abuse. In the literature, the data on the distribution of subtypes of abuse and neglect are variable. Ford et al. (2000) found that severity of physical abuse was higher than other types of trauma in children with ADHD (5). Soysal et al. (2011) investigated the relationship between injury rate and physical abuse/neglect in school-age children with ADHD and healthy controls (41). It has been reported that physical abuse and neglect should be questioned in detail in children with ADHD and history of injury. (41). Sanderud et al. also found that emotional abuse was the second factor associated with ADHD symptoms in young adults (42). Semiz et al. reported that emotional abuse and neglect are common (40). In our study, patients with ADHD differed in terms of emotional abuse, physical neglect and physical abuse scores. Emotional abuse has a direct impact on social support, self-confidence and the risk of bullying at school. Therefore, it can be considered that children with ADHD are at higher risk of physical and emotional abuse. Studies support evidence that children under 9 years of age start to exhibit behavioral problems after being exposed to early childhood trauma (43). The rate of untreated ADHD is higher in the parents of children with ADHD compared to parents of healthy children $(44,45)$. In the context of mental health preventive interventions, it has been suggested that relatives of childhood ADHD cases should be informed, checked, and ADHD treatment should be provided before children are exposed to traumatic experiences (46). Childhood traumas should be examined in adult ADHD patients who have problems in many areas of life due to ADHD, and trauma-centered therapeutic interventions should be applied if necessary $(47,48)$. In this study, the differentiation between the two groups in terms of emotional neglect and sexual abuse may be related to the fact that emotional neglect has an important place in the pathology of both depression and ADHD (15). In a recent meta-analysis, it has been reported that emotional neglect, a form of silent trauma, has a much stronger relationship with depression (49). In our opinion, the fact that sexual abuse is more dependent on the characteristics of the caregiver and the social environment (45), and that the subjects experience labeling anxiety when making selfreports for sexual abuse may have contributed to the lack of difference between the groups in our study.

When the mean trauma scores were examined in terms of ADHD subtypes, CTQ total score and trauma subtype scores were higher in combined ADHD than the other two groups. In addition, CTQ total score and other trauma scores except sexual abuse and emotional neglect were significantly higher in combined type ADHD. When these results are compared with other studies conducted in children, it is seen that du Prel Carroll et al. (2008) found a relationship between inattentive type ADHD and physical neglect, physical abuse and sexual abuse, and reported a relationship between hyperactive type ADHD and physical neglect (50). Semiz et al. also found a relationship between hyperactivity/impulsivity scores and emotional neglect and abuse, and between inattention and emotional abuse in adults (40). Since emotional neglect and sexual abuse is a non-specific risk factor for any psychiatric disorder, this may be the reason for the lack of significant difference between ADHD subtypes (15).

Since this study has a cross-sectional design, no causal relationship can be established on our results. Furthermore, retrospective questioning the presence of childhood traumas is open to errors such as anxiety of stigmatization in difficult subjects with sexual abuse, difficulty in remembering, and misremembering. The fact that the study group consisted of a patient sample hospitalized in a psychiatric ward with specific rules and conditions (limitation of duration of stay, patient-based decision-making for discharge over the course of follow-up, etc...), not including the control group, and the small sample size may affect the results of the study in terms of frequency and severity. These limitations should be considered when evaluating our results. Despite all the limitations, we believe that our study will contribute to the literature to draw attention and to provide data for childhood 
traumas in adult depressive patients with ADHD comorbidity.

\section{CONCLUSION}

In adults with depression and ADHD comorbidity, childhood trauma is more common, and depression is more severe. In the presence of severe depressive episodes, resistance to treatment, and low psychosocial functioning in adult ADHD patients, it will be beneficial for clinicians to examine childhood traumas in terms of treatment management. It is recommended that prospective studies evaluating the incidence of childhood trauma and associat- ed clinical variables in adults with ADHD and depression should be conducted.

The preliminary data of this study were presented as a verbal presentation in the 21st Annual Meeting and Clinical Education Symposium of Psychiatric Association of Turkey (19-22 April 2017/Antalya).

Correspondence address: M.D. Esin Erdogan, University of Health Sciences, Izmir Bozyaka Training and Research Hospital, Department of Psychiatry, Izmir, Turkey dresinerdogan@gmail.com

\section{REFERENCES}

1. Biederman J. Attention-deficit/hyperactivity disorder: A selective overview. Biol Psychiatry 2005;57:1215-1220.

2. Weinstein D, Staffelbach D, Biaggio M. Attention-deficit hyperactivity disorder and posttraumatic stress disorder: differential diagnosis in childhood sexual abuse. Clin Psychol Rev 2000;20:359-378.

3. Perry BD. Applying principles of neurodevelopment to clinical work with maltreated and traumatized children: The neurosequential model of therapeutics. Edited by Webb NB. New York, Guilford Press, 2006, pp. 27-52.

4. Briscoe-Smith AM, Hinshaw SP. Linkages between child abuse and attention-deficit/hyperactivity disorder in girls: behavioral and social correlates. Child Abuse Negl 2006;30:1239-1255.

5. Ford JD, Racusin R, Ellis CG, Daviss WB, Reiser J, Fleischer A, Thomas J. Child maltreatment, other trauma exposure, and posttraumatic symptomatology among children with oppositional defiant and attention deficit hyperactivity disorders. Child Maltreat 2000;5:205-217.

6. Evinç ŞG. Maternal personality characteristics, affective state, and psychopathology in relation to children's attention deficit hyperactivity symptoms and comorbid symptoms. Orta Doğu Teknik Üniversitesi, Uzmanlık Tezi. 2004.

7. Uchida M, Spencer TJ, Stephen V. Faraone SV, Biederman J. Adult Outcome of ADHD: An overview of results from the MGH longitudinal family studies of pediatrically and psychiatrically referred youth with and without ADHD of both sexes. J Atten Disord 2018; 22:523-534.

8. Matsumoto T, Imamura F. Association between childhood attention-deficit-hyperactivity symptoms and adulthood dissociation in male inmates: Preliminary report. Clin Neurosci 2007;61:444-446.

9. Semiz UB, Cengiz FF, Oner O. Yetişkin dikkat eksikliği hiperaktivite bozukluğu ve örselenme. Klinik Psikofarmakol Bulteni 2012;22:29.

10. Fischer AG, Bau CH, Grevet EH, Salgado CA, Victor MM, Kalil KL, Sousa NO, Garcia CR, Belmonte-de-Abreu P. The role of comorbid major depressive disorder in the clinical presentation of adult ADHD. J Psychiatr Res 2007;41:991-996.

11. Örsel S, Karadağ H, Kahiloğulları AK, Akgün AE. Psikiyatri hastalarında çocukluk çağı travmalarının sıklı̆̆ ve psikopatoloji ile ilişkisi. Anadolu Psikiyatri Derg 2011;12:130-136.

12. Bülbül F, Çakır Ü, Ülkü C, Üre İ, Karabatak O, Alpak G. Yineleyen ve ilk atak depresyonda çocukluk çağı ruhsal travmalarının yeri. Anadolu Psikiyatri Derg 2013;14:93-9.

13. Widom CS, DuMont K, Czaja SJ. A prospective investigation of major depressive disorder and comorbidity in abused and neglected children grown up. Arch Gen Psychiatry 2007;64:4956.

14. Saunders BE, Villeponteaux LA, Lipovsky JA, Kilpatrick DG, Veronen LJ. Child sexual assault as a risk factor for mental disorders among women: A community survey. J Interpers Violence 1992;7:189-204.

15. Mandelli L, Petrelli C, Serrettia A. The role of specific early trauma in adult depression: A meta-analysis of published literature. Childhood trauma and adult depression. Eur Psychiatry 2015;30:665-680.

16. APA, Diagnostic and Statistical Manual of Mental Disorders Fifth Edition:DSM-5 Arlington, VA, American Psychiatric Association, 2013; 461-481.

17.Amerikan Psikiyatri Birligì, Ruhsal Bozuklukların Tanısal ve Sayımsal El Kitabı (5. basım, E. Köroglu, Çev.) 2013; Ankara: Hekimler Yayın Birligì.

18. Ward MF, Wender PH, Reimherr FW. The Wender Utah Rating Scale: an aid in the retrospective diagnosis of childhood attention deficit hyperactivity disorder. Am J Psychiatry 1993;150:885-890.

19. Öncü B, Olmez S, Sentürk V. Validity and reliability of the Turkish version of the Wender Utah Rating Scale for attentiondeficit/hyperactivity disorder in adults. Türk Psikiyatr Derg 2005;16:252-259.

20. Turgay A. DSM IV'e Dayalı Erişkin Hiperaktivite Değerlendirme Ölçeği (Yayınlanmamıs Ölçek). Toronto; 1995.

21. Günay Ş, Savran C, Aksoy UM, Maner F, Turgay A, Yargıç İ. Erişkin Dikkat Eksikliği Hiperaktivite Ölçeğinin (Adult ADD/ ADHD DSM-IV Based Diagnostic Screening and Rating Scale) dilsel eşdeğerlilik, geçerlik güvenirlik ve norm çalışması. Türkiye'de Psikiyatri 2006;8:98-107

22. Hamilton M. A rating scale for depression. J Neurol 
Neurosurg Psychiatry. 1960;23: 56-62.

23. Akdemir A, Örsel S, Dă̆ İ. Hamilton Depresyon Derecelendirme Ölçeği'nin geçerliği, güvenilirliği ve klinikte kullanımı. Psikiyatri Psikoloji Psikofarmakoloji Dergisi 1996;4:251-259.

24. Bernstein DP, Fink L, Handelsman L, Foote J, Lovejoy M, Wenzel K, Sapareto E, Ruggiero J. Initial reliability and validity of a new retrospective measure of child abuse and neglect. Am J Psychiatry 1994;151:1132-1136.

25. Şar V, Öztürk E, İkikardeş E. Çocukluk Çağı Ruhsal Travma Ölçeğinin Türkçe uyarlamasının geçerlilik ve güvenirliği. Türkiye Klinikleri J Med Sci 2012;32:1054-1063.

26. Morosini PL, Magliano L, Brambilla L, Ugolini S, Pioli R. Development, reliability and acceptability of a new version of the DSM-IV Social and Occupational Functioning Assessment Scale (SOFAS) to assess routine social functioning. Acta Psychiatr Scand 2000;101:323-329.

27. Aydemir Ö, Üçok A, Danacı AE, Canpolat T, Karadayı G, Emiroğlu B, Sarı̈̈z F. Bireysel ve sosyal performans ölçeği’nin Türkçe sürümünün geçerlilik ve güvenilirlik çalışması. Klinik Psikofarmakol Bülteni 2009;19:93-100.

28. Alpert JE, Maddocks A, Nierenberg AA, O'Sullivan R, Pava JA, Worthington JJ, Biederman J, Rosenbaum JF, Fava M. Attention deficit hyperactivity disorder in childhood among adults with major depression. Psychiatry Res 1996;62:213-219.

29. Bron TI, Bijlenga D, Verduijn J, Penninx BW, Beekman AT, Kooij JJ. Prevalence of ADHD symptoms across clinical stages of major depressive disorder. J Affect Disord 2016;197:29-35.

30. Agosti V, Chen Y, Levin FR. Does Attention Deficit Hyperactivity Disorder increase the risk of suicide attempts? J Affect Disord 2011;133:595-599.

31. Patros CH, Hudec KL, Alderson RM, Kasper LJ, Davidson C, Wingate LR. Symptoms of attention-deficit/hyperactivity disorder (ADHD) moderate suicidal behaviors in college students with depressed mood. J Clin Psychol 2013;69:980-993.

32. Stickley A, Tachimori H, Inoue Y, Shinkai T, Yoshimura R, Nakamura J, Morita G, Nishii S, Tokutsu Y, Otsuka Y, Egashira $\mathrm{K}$, Inoue $\mathrm{M}$, Kubo $\mathrm{T}$, Tesen $\mathrm{H}$, Takashima $\mathrm{N}$, Tominaga $\mathrm{H}$, Koyanagi A, Kamio Y. Attention-deficit/hyperactivity disorder symptoms and suicidal behavior in adult psychiatric outpatients. Psychiatry Clin Neurosci 2018;72:713-722.

33. Sobanski E, Bruggemann D, Alm B, Kern S, Deschner M, Schubert T, Philipsen A, Rietschel M. Psychiatric comorbidity and functional impairment in a clinically referred sample of adults with attention-deficit/hyperactivity disorder (ADHD). Eur Arch Psychiatry Clin Neurosci 2007;257:371-377.

34. Secnik K, Swensen A, Lage MJ. Comorbidities and costs of adult patients diagnosed with attention-deficit hyperactivity disorder. Pharmacoeconomics 2005;23:93-102.

35. Imagawa H, Nagar SP, Montgomery W, Nakamura T, Sato M, Davis KL. Treatment patterns, health care resource utilization, and costs in Japanese adults with attention-deficit hyperactivity disorder treated with atomoxetine. Neuropsychiatr Dis Treat 2018;14:611-621.

36. Tuscic JS, Flander BG; Mateskovic D. The consequences of childhood abuse. Pediatrics Today 2013;9(1):24-35.
37. Thomson FT, Mehta R, Valeo A. Establishing a link between attention deficit disorder/attention deficit hyperactivity disorder and childhood physical abuse. J Aggress Maltreat Trauma 2014;23:188-198.

38. Brown NM, Brown SN, Brigs RD, German M, Belamarich PF, Oyuke SO. Associations between adverse childhood experiences and ADHD diagnosis and severity. Acad Pediatr 2017; $17: 349-355$.

39. Rucklidge JJ, Brown DL, Crawford S, Kaplan BJ. Retrospective reports of childhood trauma in adults with ADHD. J Atten Disord 2006;9:631-641.

40. Semiz ÜB, Öner Ö, Cengiz FF, Bilici M. Childhood abuse and neglect in adult attention deficit/hyperactivity disorder. Klinik Psikofarmakol Bulteni 2017;27 (4):344-348.

41. Soysal AŞ, Bayoğlu BU, Gücüyener K. Dikkat eksikliği hiperaktivite bozukluğu ile örtülü fiziksel istismar ve ihmal. Çocuk Sağlığı ve Hastalıkları Dergisi 2011;54:148-153.

42. Sanderud K, Murphy S, Elklit A. Child maltreatment and ADHD symptoms in a sample of young adults. Eur $\mathbf{J}$ Psychotraumatol 2016;7: 10.3402/ejpt.v7.32061.

43. Hunt TKA, Slack KS, Berger LM. Adverse childhood experiences and behavioral problems in middle childhood. Child Abuse Negl 2017;67:391-402.

44. Camcıoğlu T, Yıldız Ö, Ağaoğlu B. DEHB tanısı konmuş çocukların anne babalarında DEHB sıklığı. Anadolu Psikiyatri Derg 2011;12:212-220.

45. Evinç ŞG, Foto Özdemir D. Dikkat eksikliği hiperaktivite bozukluğunda risk ve sonuçları açısından çocuk istismarına bir bakış. Psikiyatride Güncel Yaklaşımlar 2015;7:166-177.

46. Barlow J, Coren E, Stewart-Brown S. Meta-analysis of the effectiveness of parenting programmes in improving maternal psychosocial health. Br J Gen Pract 2002; 52:223-233.

47. Fuller-Thomson E, Lewis DA. The relationship between early adversities and attention-deficit/hyperactivity disorder. Child Abuse Negl 2015;47:94-101.

48. Fayyad J, Sampson NA, Hwang I, Adamowski T, AguilarGaxiola S, Al-Hamzawi A, Andrade LH, Borges G, de Girolamo G, Florescu S, Gureje O, Haro JM, Hu C, Karam EG, Lee S, Navarro-Mateu F, O'Neill S, Pennell BE, Piazza M, Posada-Villa J, Ten Have M, Torres Y, Xavier M, Zaslavsky AM, Kessler RC; WHO World Mental Health Survey Collaborators. Fayyad J, Sampson NA; Hwang I et al. The descriptive epidemiology of DSM-IV Adult ADHD in the World Health Organization World Mental Health Surveys. Atten Defic Hyperact Disord 2017;9:47-65.

49. Infurna MR, Reichl C, Parzer P, Schimmenti A, Bifulco A, Kaess M. Associations between depression and specific childhood experiences of abuse and neglect: A meta-analysis. J Affect Disord 2016;190:47-55.

50. du Prel Carroll X, Yi H, Liang Y, Pang K, Leeper-Woodford S, Riccardi P, Liang X. Family-environmental factors associated with attention deficit hyperactivity disorder in Chinese children: a case-control study. PLoS One 2012;7:e50543. 